\title{
Spatio-temporal changes in the caddisfly (Trichoptera) communities of the river Lea basin (Basque Country, North Spain)
}

\author{
A. Basaguren ${ }^{1}$ \\ E. Orivel
}

Keywords : Trichoptera, correspondence analysis, rivers, Basque Country.

In the Lea River basin, 47 taxa of caddisflies have been found belonging to 32 genera and 15 families. Rhyacophilidae (5 species), Hydropsychidae (6 species), Limnophilidae (4 species) and Polycentropodidae (4 species) were the dominant families; Hydropsyche pellucidula being the most abundant species. Using all these taxa as entities, an ordination of the River Lea Basin has been made by means of Correspondance Analysis. The ordinations with higher ecological meaning were obtained on the plane of the second and third axes, which explained about $21 \%$ of the total variance. According to this ordination the following zones characterized by different communities of caddisf lies could be identified in this basin : the headwater of the main river, the small tributaries and a downstream sequence from site 1 to site 5 of the main river as well as a downstream sequence from site 1 to site 2 of its principal tributary. Along the second axi,s a seasonal succession from spring to summer and autumn could be observed in the main river.

Changements spatio-temporets dans les groupements de Trichoptères (Trichoptera) du bassin de la rivière Lea (Pays-Basque, Espagne). Mots clés : Trichoptères, analyse des correspondances, rivières, Pays-Basque.

Dans le bassin de la rivière Lea, 47 taxa de trichoptères appartenant à 32 genres et 15 familles ont été trouvés. Les Rhyacophilidae (5 espèces), les Hydropsychidae (6 espèces), les Limnephilidae (4 espèces) et les Polycentropodidae (4 espèces) sont les familles dominantes: Hydropsyche pellucidula est l'espèce la plus abondante. En utilisant tous ces taxa comme entités, une étude du bassin de la rivière Lea a été effectuée à l'aide d'une analyse des correspondances. Les groupements qui se situent sur le plan du deuxieme et troisième axes expliquent environ $21 \%$ de la variance totale. Ces groupements ont permis de caractériser plusieurs zones par différentes communautés de trichoptères : la partie la plus haute du bas. sin, les affluents, une succession amont (stations 1-5) dans la rivière principale et une succession aval (stations 1-2) dans l'affluent principal. Le deuxième axe montre une succession saisonnière du printemps à l'été et à l'au tomne, dans la rivière principale.

\section{Introduction}

Trichoptera have recently been the object of several studies in different rivers of Spain (Garcia del Jalón 1982, Puig 1981, Gonzalez et al., 1987). However, there are no data on this group of insects from the rivers of Biscay (Basque Country, northern Spain) despite the importance of these organisms in the shallow, fast-running waters where stones and

1. Laboratorio de Ecologia. Faculdad de Ciencias. Unviersidad del País Vasco. Apdo 644. Bilbao 48080 Spain. gravel beds dominate for most of their length. In the context of a comprehensive study performed between 1985 and 1988 and focused on the physicochemical and biological featu res of the hydrographic network of Biscay (Euskoiker 1988), the River Lea Basin has been studied with the aim of knowing the caddisfly communities present in the different courses and to relate their abundance and distribution to selected physico-chemical variables. In this paper we report the different communities and the seasonal changes identified in the River Lea basin as assessed by multivariate analysis. 


\section{Study area}

The River Lea rises at $1026 \mathrm{~m}$ above sea level and flows for about $20 \mathrm{~km}$. draining a catchment area of $81,18 \mathrm{~km}^{2}$ (Fig. 1). It is a small and fast-running river which traverse sandstones at its headwater and calcareous rocks at the downstream reaches. Riffle areas with stone and gravel beds extend along $i$ ts length until the tidal limit where it receives the main source of pollution.

The climate is typically warm-temperate with mean annual precipitation greater than $1500 \mathrm{~mm}$ regulary distributed in winter and spring, but with short dry periods chiefly in summer. During the study period a persistent dryness extended until mid-autumn.

Agriculture and farming are the main activities of the catchment which is one of the least perturbed in the Basque Country, maintaining a well conserved riparian vegetation for most of its length.

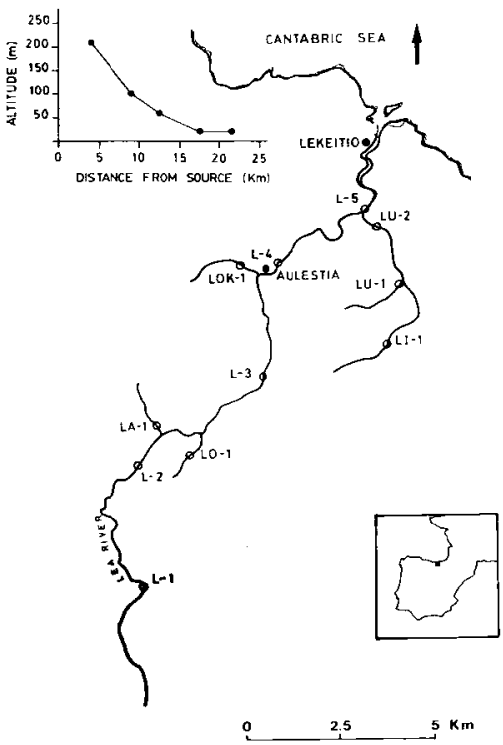

Fig. 1. Study area and sampling sites.

\section{Methods}

11 sites were located on the main river and its tributaries and visited in winter, spring, summer and autumn for macroinvertebrate sampling as well as for physico-chemical data. Criteria for selection were chiefly distance from source, substrate typology, land use and accessibility. Five samples were collected from each site and in each season by means of a kicktype sampler through transects covering an area of about $0,3 \mathrm{~m}^{2}$ in riffle areas. Parallel sets of samples were taken from pool areas but only riffle samples corresponding to spring, summer and autumn were analyzed. Individual samples at each site were combined to form one composite sample por season. The Kick sampler was provided with a mesh size of 200 ${ }_{\mu} \mathrm{m}$ and a frame of about $20,5 \times 25 \mathrm{~cm}$. Samples were washed in the field through two sieves (mesh size of $0,2 \mathrm{~mm}$ and $1 \mathrm{~cm}$ ) and then fixed in $4 \%$ formalin. At the laboratory, samples were washed again through a sieve (mesh size of $0,5 \mathrm{~mm}$ ) and organisms stored in $70 \%$ ethyl alcohol. Adults and pupae were also catch to helping in larvae identification.

After transformation of total abundance of each taxon in each sample to $\log (\times+1)$ to avoid overdispersion of data, a Correspondence Analysis was performed to a data matrix of 47 taxa and 31 samples using the SPAD program (Lebart \& Morineau 1982). This ordination technique is less affected than principal component analysis by data matrices containing many zeros. Several ordination analyses were perfor: med taken out species only present in a few places as well as young larvae but the position of the remaining species on the space of the first three axes was similar to the position that presented in the analysis performed with all taxa being the later the analysis in which the position of the sites had the best ecological meaning. Thus, in this paper only, the analysis performed with all taxa and all sites is presented. Ordination scores of CA were correlated to selected physico-chemical variables using the Pearson coefficient.

\section{Results}

Conductivity values oscillated between $127 \mu \mathrm{S} / \mathrm{cm}$ in a small stream in autumn (LO)to $375 \mu \mathrm{S} / \mathrm{cm}$ in the last station of the main river in summer. Conductivity increased slighthly downst ream, being more mar. ked the seasonal changes. Oxygen values were always very high at all sites decreasing sligthly in summer 

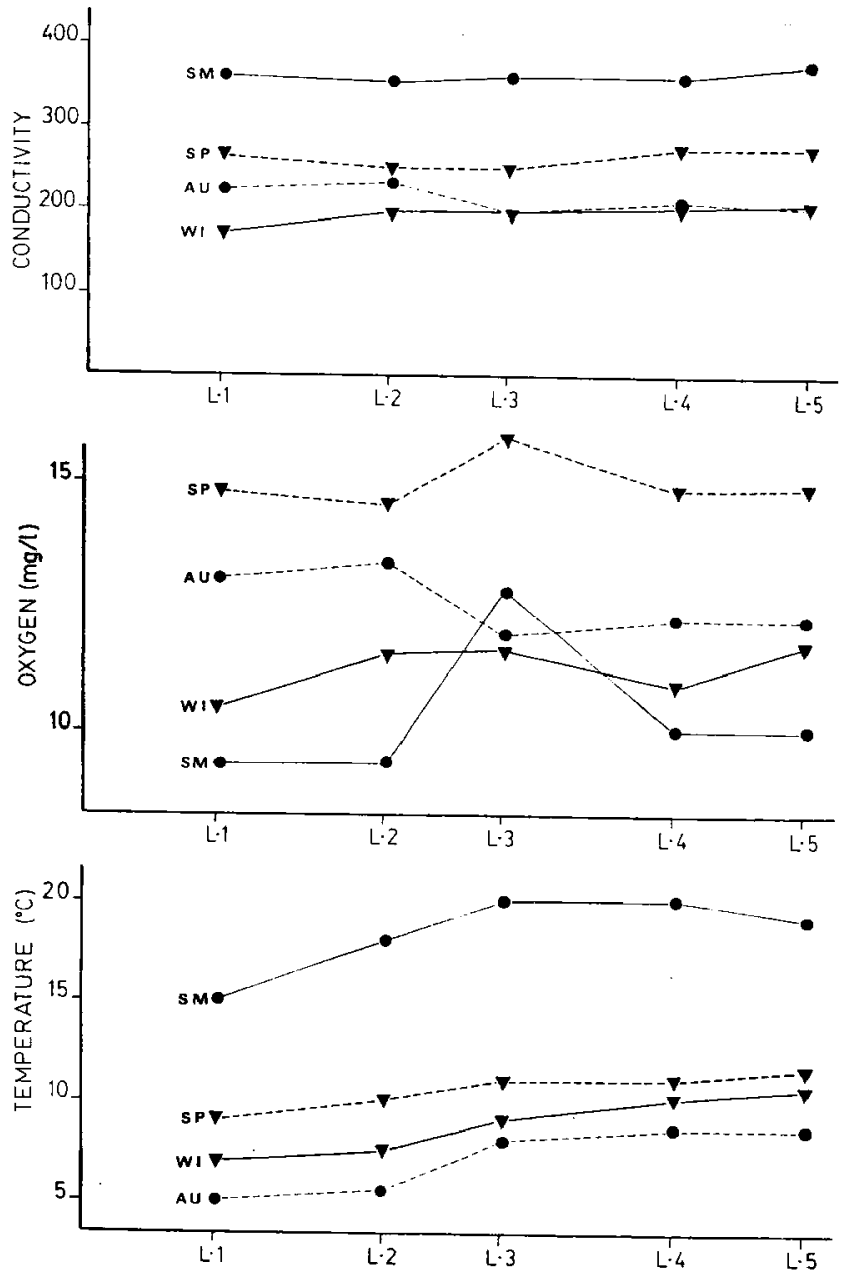

Fig. 2. Spatio-temoral changes in water conductivity, oxygen and temperature in the main river. Code as in Table 1. 
when values of about $90 \%$ saturation level were found at sites 1 and 2 of the main river and at site LA-1. Temperature ranged from $5^{\circ} \mathrm{C}$ in autumn to $20^{\circ} \mathrm{C}$ in summer, being always lower upstream (Fig. 2). River flow oscillated between $6 \mathrm{~m}^{3 / 5}$ at the last station of the main river in spring to less than $0.5 \mathrm{~m}^{3 / 5}$ in the effluents in summer. Width ranged from $14 \mathrm{~m}$ in the effluents and first site of the main river to $9-13 \mathrm{~m}$ in the other stations of the main river.

In the Lea River basin 47 taxa of caddisflies were found belonging to 14 families and 32 genera. Among them, Rhyacophilidae (5 species), Hydropsychidae (6 species), Limnephilidae (4 species), and Polycentropolidae ( 4 species) were the dominant species (Table I). These organisms were distributed through out the basin denoting that it is relatively un-perturbed.

As a consequence of the numerical dominance of Hydropsyche pelltcidula in summer, specific diversity was maximal at most sites in spring and/or in autumn where individual numbers were best partitioned into different species. An exception was site 4 of the main river where specific diversity was maximal in summer.

Diversity was greatest in the main river, being hig. hest at site 5 in autumn coinciding with the relative decreases of hydropsychid numbers (Fig. 3). Diversity decreased drastically at site 3 of the main river located downstream in the locality of Aulestia and was low too in several streams dominated by one or two species of hydnopsychids.

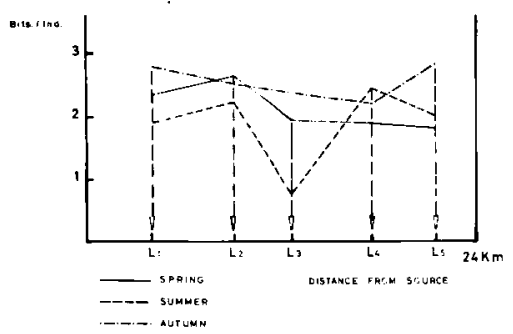

Fig 3. Spatiotemporal changes in species diversity along the main river.

The most ubiquitous species were Rhyacophila denticulata, Rhyacophila relicta, Hydropsyche pellucidula and $H y d r o p s y c h e$ siltalai, $H$. pellucidula being the most abundant species.
Rhyacophila denticulata coexisted at several sites with Rhyacophila relicta, this being most abundant in sites 2 and 3 of the main river and in several streams. Coexistence was also observed between Hydropsyche species ; being especially evident between $H y d r o p s y c h e$ pellucidula and $H y d r o p s y c h e$ siltalai which showed their maximum at the middle and lower reaches of the main river.

The results of the ordination analysis appear in Fig. 4 showing the plane of the second and third axes. The first axis was considered misleading because it separated small unidentified hydropsy. chids from Hydropsyche siltalai on the basis that the former, wich only appeared at one site in one season, do not coexist with the lat ter which, by contrast, was widely distributed. However the plane of the second and third axes showed a distribution of sam. ples and taxa that could be interpreted in ecological terms. These two axes explained about $21 \%$ of the total variance and are mainly related to altitude. At the left side of axis two are the headwater of the main river and the sites located upstream in the tributaries. At the right side appear sites 2,3,4 and 5 of the main river. The third axis separates the headwater of the main river from the small tributaries. Along this axis can also be observed the downstream sequence of species from site 1 to site 5 of the main river and the downstream changes from site 1 to site 2 of the principal tributary. A seasonal succession can be observed in the main river along the second axis from spring to summer and autumn. In the main river the longitudinal changes are chiefly based in the downst ream increases of hydropsychid larvae and on the presence of Chimarra marginata and Chetmatopsyche lepida in the lower reaches. In the principal tributary the downstream changes are mainly based on the presence at the first site of Agapetus delicatulus as well as by the downstream increases in hydropsychid larvae.

Several species such as Agapetus delicatulus, Silo . nigricomis, Glossosoma spoliatum, Womaldia subnigra and Plectrocnemia conspersa appear in the small tributaries whilst by contrast, Philopotamus montanus, Rhyacophila tristis, Rhyacophila martynovi and $H y d r o p s y c h e$ dinarica are characteristic of the first station of the main river.

On the other hand, the seasonal succession that is obseved in the main river is based on the increases in number of individuals in summer and/or in autumn. 

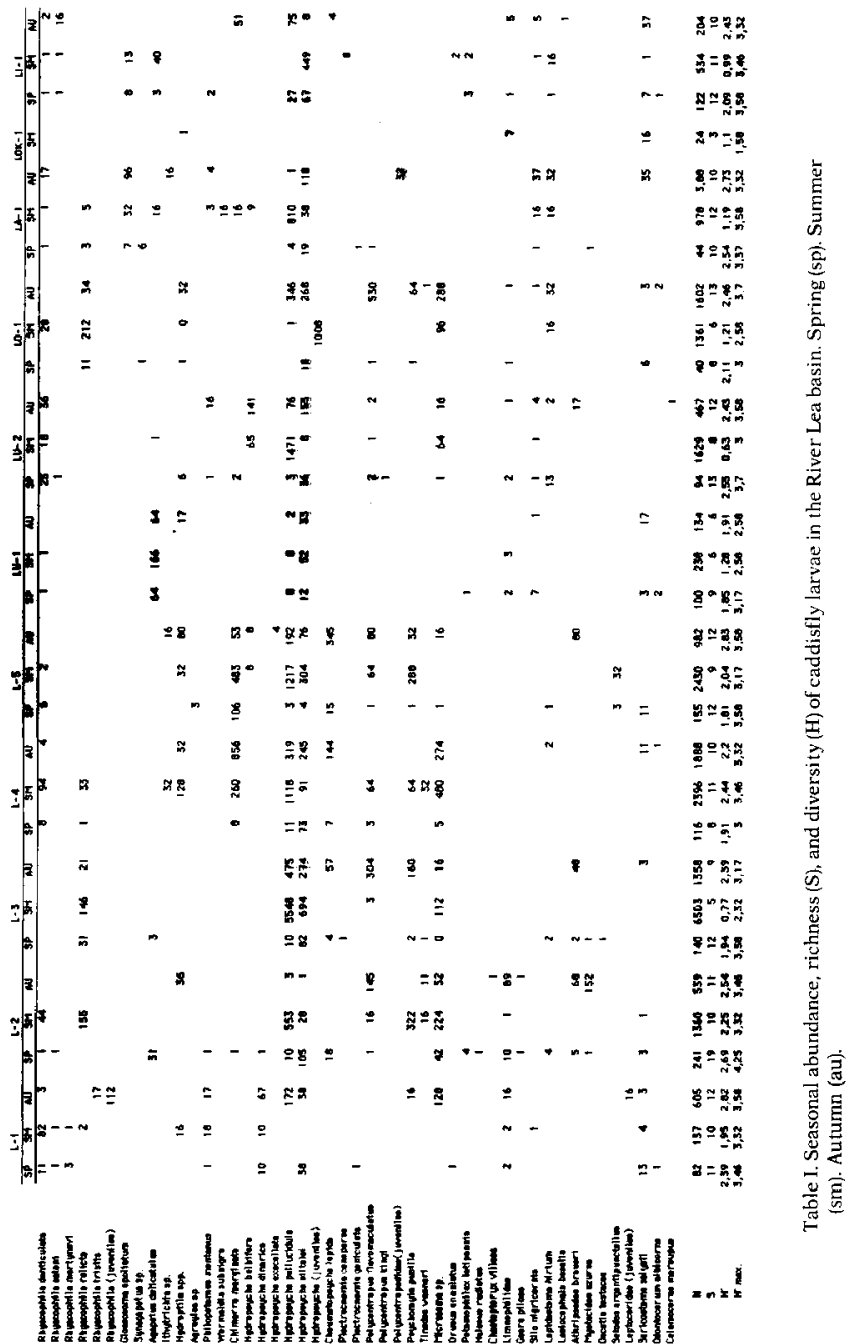

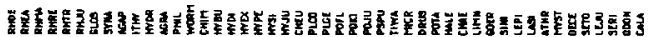



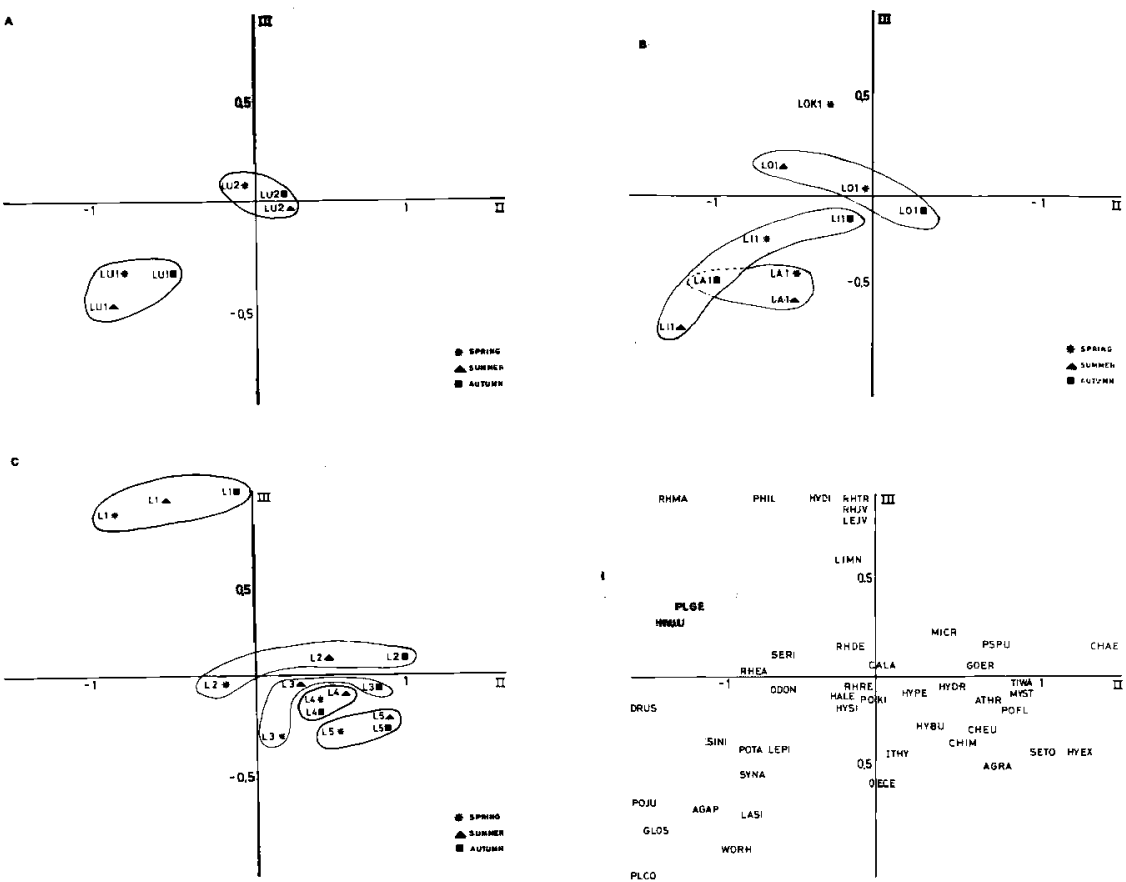

Fig. 4. Position of taxa and samples in the plane of the second and third axes from CA. Taxa code as in Table 1.(A) and (B) : small tributaries, (C) : the main river.

Correlation analyses between selected physicochemical variables and the scores of the second and third axes of the correspondence analysis appear in table II. The correlation coefficient was significant for al titude with both $\mathbf{F} 2$ and $\mathbf{F} 3$ scores and for width and F2 score.

Table II. Correlation coefficients among selected physicochemical variables and the second and third axes $f$ rom correspondances analysis of taxa $\left.\left({ }^{*} \mathrm{p} \quad 0.05\right)^{\star *} \mathrm{p} \quad 0.01\right)$.

\begin{tabular}{lcccc}
\hline & Altitude & Width & Conductivity & Oxygen \\
$\mathbf{F}_{2}$ & ${ }^{*}-0.363$ & ${ }^{*} 0.485$ & 0.141 & -0.008 \\
$\mathbf{F}_{3}$ & ${ }^{*} 0.682$ & -0.098 & 0.103 & 0.043 \\
\hline
\end{tabular}

\section{Discussion}

The ordination of taxa and samples performed by means of correspondence analysis summarises well the spatio-temporal changes that occur in the structure of caddisfly communities.

According to this analysis in the plane of the axes two and three differences were found between the head water of the main river and the sites located on the small tributaries. On the other hand, a downstream sequence from site 1 to site 5 of the main river could be observed as well as seasonal succession from spring to autumn. 
The caddisfly community which supports the headwater of the main river only appears at this site and may be considered as representative of cool, fast-running waters (Décamps 1967, Verneaux \& Rezzouk 1973, Herranz \& García de Jalón 1984, Garcia de Jalón 1986). Several authors have reported the incidence of thermal regimes in the distribution of stream insects (Décamps 1967, Hildrew \& Edington 1979, Ward \& Stanford 1982, Stroot 1984, Valett \& Stanford 1987). In this river although it is short and fast-running, temperature changes are always higher at the lower reaches, chiefly in summer and autumn (Orive et al. 1988) and this factor may control the downstream distribution of these caddisflies.

Another caddisfly community is mainly constituted by Rhyacophila denticulata, Hydropsyche siltalai, Hydropsyche pellucidula, Agapetus delicatulus, Silo nigricornis and some species of Limnephilidae. This community appeared in the small streams, tributaries of the main river, coinciding with the lower values of diversity. The species of this community are generally more widespread than those which appeared at site 1 of the main river and representatives of sites downstream of the sources (Giudicelli et al. 1980, da Terra 1981). The last community, which appeared through most reaches of the main river contained several species also found in the small tributaries as for example, Rhyacophila relicta, Rhyacophila denticulata, Hydropsyche siltalai and Hydropsyche pellucidula in addition to Psychomyia pusilla, Polycentropus flavomaculatus, Hydroptila spp., Athripsodes braueri, Mystacides azurea, Cheumatopsyche lepida and Chimarra marginata. The downstream sequence of species from site 1 to site 5 of the main river agrees well with that found by Illies \& Botosaneanu (1963). Hildrew \& Edington (1979), Giudicelli et al. (1980), Bournaud et al. 1980 and Stroot (1984). The most abundant and ubiquitous species in this downstream sequence were $H y d r o p s y c h e$ pellucidula and Hydropsyche siltalat whilst, by contrast, Chimarra marginata and Cheumatospyche lepida appeared mainly in the last reaches.

It is well stablished that congeneric species coexist in streams by means of several strategies (Boon 1979, Hildrew \& Edington 1979, Décamps 1967, Malas \& Wallace 1977, Andersen \& Klubnes 1983, Bournaud et al., 1982, Higler \& Tolkamp 1983). In this case, the coexistence of Hydropsyche pellucidula and Hydropsyche siltalai have been observed at most sites of the basin, whilst Rhyacophila denticulata and Rhyacophila relicta coexisted only in some places and were never abundant.,

Along the second axis it is possible to observe the seasonal succession from spring to autumn that occurs in the main river. This change is mainly based on the temporal changes in the abundance of several species such as Hydropsyche siltalai and Hydropsyche pellucidula which generally show their maximum in summer and Cheumatopsyche lepida and Polycentropus flavomaculatus with maximum abundance generally in autumn.

The diversity of association in the main river is relatively high as compared with that recorded in the small tributaries as a consequence of the fact that this river is free of any major source of pollution and in this cases the organisms can exploit a more diverse and fluctuating environment as discussed by Vannote el al. (1980).

\section{Acknowledgements}

We are grateful to Dr M. Ladle for correcting the manuscript, to Dr Garcia de Jalón for helping in specimen identification and to the Diputacion Foral of Biscay for the finantial support which has made this study possible.

\section{References}

Andersen (T.) \& Klubnes (R.). 1983. - The Life Histories of Hydropsyche siltalai (Dohler, 1963) and Hydropsyche pellucidula (Curtis, 1834) (Trichoptera, Hydropsychidae) in a West Norwegian River. Aquat. Ins., $5: 51-62$.

Boor (P.J.). 1979. - Studies on the spatial and temporal distribution of larval Hydropsychidae in the North Tyne River System (Northern England). Arch. Hydrobiol., 85 : 336-359.

Bouınaud (M.), Keck (G.) \& Richoux (P.). 1980. - Les prélèvements de macroinvertébrés benthiques en tant que révélateurs de la physionomie d'une rivière. Annls Limnol., 16:55-75.

Bournaud (M.), Tachet (H.) \& Perrin (J.F.). 1982. - Les Hydropsy chidae (Trichoptera) du Haut-Rhône entre Genève et Lyon. Annls Limnol., 18 : 61-80.

Décamps (H.). 1967. - Ecologie des Trichoptères de la Vallée d'Aure (Hautes-Pyrénées). Annls Limnol., 3 : 399-577,

Euskoiker. 1988. - Caracterización Fisico-Quimica y Biológica de la Red Hidrográfica de Bizkaia. Informe Final. Diputación Foral de Bizkaia. Bilbao.

Garcia de Jalon (D.). 1982, - Contribución a la zoogeografía de los tricópteros espanoles. Shilap. Rev. Lepid., (37) : 75-78 ; (38): 157-165: (39): $237-244$.

Garcia de Jalon (D.). 1986. - Los Hydropsychidae (Trichoptera) de la cuenca del Duero. Bol. Asoc. Esp. Emtom., 10 : 127-138.

Giudicelli (J.). Dia (A.) \& Legier (P.). 1980. - Etude Hydrobiologique d'une Rivière de Région Méditerranéenue, L'Argens (Var, France). Habitats, Hydrochimic, Distribution de la Faune Benthique. Bijdr. Dierk, $50: 303-341$. 
Gonzalez (M.A.), Garcia de Jalon (D.) \& Terra (L.S.W.). 1987. Faunistic studies on Iberian trichoptera: A historical survey and present state of knowledge. Proc, of the $5 \mathrm{th}$ Int. Symp. on Trichopiera Bournaud (M.) and Tachet (H.) (eds.). Dordrecht, The Netherlands, 85-90.

Herranz (J.M.) \& Garcia de Jalon (D.). 1984. - Distribución de las especies del género Hydropsyche (O. Trichoptera, Hydropsychidae) en la cuenca del Al to Tajo (Guadalajara), Limnética, 1 : 203-206.

Higler (L.W.G.) \& Tolkamp (H.H.). 1983. - Hydropsychidae as bioindicators. Environmental Monitoring and Assessment, 3 : 331-341.

Hildrew (A.G.) \& Edington (J.M.). 1979. - Factors facilitating the coexistence of Hydropsychid caddis larvae (Trichoptera) in the same river system. J. Anim. Ecol., 48: 557-576.

Illies (J.) \& Botosaneanu (L.). 1963. - Problèmes et méthodes de la classification et de la zonation écologique des eaux courantes, considérées sur tout du point de vue faunistique. Mitt. int. Ver, Limnol, 12:1-57.

Lebart (L.) \& Morineau (I.A.). 1982. - Système portable pour l'analyse des donnees. SPAD. Cesia, Paris.

Malas (D.) \& Wallace (J.B.). 1977. - Strategies for coexistence in three species of net-spinning caddisflies (Trichoptera) in second-order southern Appalachian streams. Can. J. Zool., 55 : 1829-1840.

Orive (E.), Basaguren (A.), Bikuna (B.G.) \& Cacho (M.). 1988 - A comparative study of water mineralization and trophic status in main water courses of Biscay (Basque Country) by means of factorial analysis. Water Research (in press).
Puig (M.A.), Bautista (I.). Tort (M.J.) \& Prat (N.). 1981. - Les larves de Trichoptera de la rivière Llobregat (Catalogne, Espagne). Dist ribution longitudinale et relation avec la qualité de l'eau. Proc. of the 3thd. Int. Symp. on Trichoptera, Morett i (G.P.) (ed), Junk. The Hague, pp. 303-310.

Stroot (Ph.). 1984. - Faunistique et répartition longitudinale des Trichoptères dans une rivière salmonicole de basse montagne, en Belgique. Hydrobiologia, 108 : 245-258.

Terra (L.S.W.) da. 1981. - Lis ta faunistica de tricópteros de Por. tugal. Bol. Soc. Port. Entomol., 12 : 1-42.

Valett (H.M.) \& Stanford (J.A.). 1987. - Food quality and hydropsychid caddisfly density in a lake outlet stream in Glacier National Park, Montana, USA. Can. J. Fish. Aquat. Sci., 44 : 77-82.

Vannote (R.L.), Minshal (G.W.), Curnmins (K.W.), Sedell (J.R.) \& Cushing (C.E.). 1980. - The river continuum concept. Can. J. Fish. Aquat. Sci, $37: 131-162$,

Verneaux (J.) \& Rezzouk (M.). 1974. - Les structures d'un grand cours d'eau à salmonidés : La Loue (Massif du Jura). Essai typologique et problèmes des relations entre expèces et milieu. Annls Limnol., $10: 131-162$.

Ward (J.V.) \& Stanford (J.A.). 1982. - Thermal responses in the evolutionary ecology of aquatic insects. Ann Rev. Entomol. 27 : 97-117. 